\title{
Duyum, Algı ve Marka: Tüketici Tutumlarına Yönelik Üç Boyutlu Bir Değerlendirme ${ }^{1}$
}

\author{
Esra BÜDÜN AYDIN ${ }^{2}$
}

Öz

Ürünlerin ve markaların yavaş yavaş birbirine benzemeye başlaması, geleneksel yöntemlerin günümüz tüketicilerini artık yeterince etkileyememesi gibi nedenler, markaları farklı stratejiler geliştirmeye yöneltmiştir. Bu stratejilerden biri ise tüketici algı ve tutumlarını beş duyu aracıllğıyla etkilemeyi amaçlayan duyusal markalamadır. Duyusal markalamada; renk, ses, koku, doku ve tat uyarıcıları ile tüketici algıları bilinçli ve sistematik olarak şekillendirilmektedir. Bu çalışmada duyuların, tüketicilerin markaya ilişkin tutum oluşturmalarındaki etkisine yönelik bir değerlendirme yapılmıştır. Bu değerlendirme tutumun öğeleri olan bilişsel, duygusal ve davranışsal boyutları aracilığılla gerçekleştirilmiştir. Değerlendirme sonucuna göre tüketicilerin ürün veya markayla ilgili sahip oldukları bilgi düzeyi, his ve niyetin, markaya yönelik algılamaları ve tutumları etkilediği görülmüştür. Diğer yandan marka algis1 boyutları olan marka bilinirliği, marka çağrışımları, algılanan kalite ve marka sadakatinin, beş duyunun tamamından ayr1 ayrı etkilendiği görülmüştür. Bu etki düzeyi ise markanın veya ürünün niteliğine göre farkllılk göstermektedir. Özellikle de alanyazın kaynaklarına göre duyuların tüketicileri, bilişsel tanımlar ve duygusal şemalar yoluyla motive ederek davranışal eyleme sevk ettiği sonucuna varılmıştır.

Anabtar Kelimeler: Duyu, Alg1, Tutum, Duyusal Markalama

\section{Sensation, Perception and Brand: A Three-Dimensional Evaluation of Consumer}

\section{Attitudes}

\section{Abstract}

Today products and brands are gradually becoming similar to each other, and traditional methods do not affect today's consumers enough because of such reasons it led brands to struggle to develop different strategies. One of these strategies is sensory marking, which aims to influence consumer perceptions and attitudes through five senses. Sensory branding; Consumer perceptions are consciously and systematically shaped with color, sound, smell, texture and taste stimulants. In this study, extant literature relevant to the effect of senses on consumers' attitudes towards the brand examined. This assessment was carried out through the cognitive, emotional and behavioral dimensions of the attitude. According to the results of the evaluation, it was seen that the level of knowledge, feeling and intention of the consumers about the product or brand affect their perceptions and attitudes towards the brand. On the other hand, brand awareness, brand associations, perceived quality and brand loyalty, which are dimensions of brand perception, were observed to be affected by all five senses separately. This level of influence varies according to the nature of the brand or product. According to the sources of the literature it was concluded that the senses motivate consumers through cognitive descriptions and emotional schemas and lead them to behavioral action.

Key Words: Sensation, Perception, Attitude, Sensory Branding

\section{Atıf İçin / Please Cite As:}

Büdün Aydın, E. (2021). Duyum, alg1 ve marka: Tüketici tutumlarına yönelik üç boyutlu bir değerlendirme. Manas Sosyal Arasttrmalar Dergisi, 10(4), 2528-2544.

Geliş Tarihi / Received Date: 23.02.2021

Kabul Tarihi / Accepted Date: 19.05.2021

\footnotetext{
${ }^{1}$ Bu çalışma İstanbul Üniversitesi Sosyal Bilimler Enstitüsü Halkla İlişkiler ve Tanıtım Anabilim Dalı'nda tamamlanan "Markaya Yönelik Tutum Oluşturmada Duyusal Markalama Uyaranlarının Rolü: Ev Tekstili Sektörü Üzerine Bir Araştırma” başlıklı doktora tezinden üretilmiştir.

2 Öğr. Gör. Dr. - Kırklareli Üniversitesi Pınarhisar Meslek Yüksekokulu, esrabudun@klu.edu.tr

(D) ORCID: 0000-0003-4533-8657
} 


\section{Giriş}

Tüketiciler gün içerisinde yoğun olarak çok çeşitli iletilere maruz kalmaktadır. Bu iletilerin alınması, anlamlandırılması ve değerlendirilmesi ise kişiden kişiye farklılık göstermektedir. Çünkü algı doğası gereği özneldir. Bu nedenle tıpkı iletilerin alınması gibi dış çevreden alınan duyusal uyarıcıların da tüketicileri aynı oranda etkilemesi beklenemez (Büdün ve Ertürk, 2020, s. 57). Bu farkllllk tüketici davranışlarının öngörülmesi ve uzun vadede işe yarar bir strateji geliştirmede de markaları oldukça zorlamaktadır. Ancak beş duyu ile elde edilen girdilerin tüketicilerde birden çok temas noktasına değinecek şekilde kurgulanması, tüketici algı ve tutumlarını yönlendirmede başarının kapısını aralamaktadır.

İnsanoğlunun en temel deneyimi renk, parlaklık, ses seviyesi ve yoğunluğu veya koku ile ilgili duyu organının uyarıldığı duyudur (Mather, 2011, s. 18). Duyular ile edindiğimiz ilk farkındalık ise duyumdur. Örneğin gözün ışığa, dilin lezzete, cildin dokuya verdiği tepki tüketicilerin belli bir nesneyi değerlendirmesini sağlayan temel deneyimdir (Solomon, 2017, s. 98; Schiffman ve Wisenblit, 2015, s. 116117). Duyusal girdiler sayesinde çevresel değişkenlerin farkına varabilen birey, bu sayede anlamlandırma sürecini aktif hale getirmektedir. Söz konusu duyusal girdileri beynin ilgili birimine ileterek nöral temsil şekline dönüştürmek ise duyu sistemlerinin görevidir (Hoeksema, Fredrickson, Loftus ve Wagenaar 2009, s. 110). Beş duyu sisteminin uyarıcıları işleyebilmesi ise uyaranların yeterli yoğunluğa sahip olmasını gerektirmektedir. Bir logonun şekli, rengi, parlaklığı veya bir gida maddesinin çıkardığı ses ile tadı temel deneyimlerin kaynağıdır.

Bu çalışmada öncelikle duyusal uyarıcılar olan görme, işitme, koklama, dokunma ve tatmanın çalışma prensipleri aktarılmıştır. Ardından duyusal markalama stratejisinin nasıl kurulduğuna ilişkin beş duyu özelinde açıklamalar yapılmıştır. Duyusal uyarıcıların tüketicilerin algı ve tutumlarına olan etkisi aktarılmışır. Ardından ise marka algısının boyutları olan marka bilinirliği, algılanan kalite, marka çağrışımları ve marka sadakatinin kavramsal ard alanı verilmiştir. Son olarak çalışmanın genel amacı olan duyusal uyarıcıların marka algısındaki rolüne odaklanılmış ve tüketicilerin tutumlarına yönelik üç boyutlu bir değerlendirme yapilmıştır.

\section{Duyusal Uyarıcıların Çalışma Prensibi}

Duyusal uyarıcıların her biri çevreden gelen sinyalleri farklı duyumsama ve algilama süresine dahil ettiğinden farklı çalışma prensiplerine sahiptir. Görme duyusu, gözler aracilı̆̆yla algilanabilecek elektromanyetik dalga dağılımı ile 35-40 kilometre uzaktaki nesneleri görebilecek kapasiteye ve göze yakın olan nesnelerin görülebilmesinin yanı sıra milyarlarca uzaktaki yıldızları görebilme kapasitesine sahiptir (Cüceloğlu, 2006, s. 112-113). Çalışma prensibi açısından bakıldığında mekanizma olarak gözün görme spektrumundaki elektromanyetik dalgalar, göz merceği ve retina üzerinde bulunan alıcılarda yoğunlaşmakta ve 1şığa duyarlı pigmentlerde çözünerek sinir akımı ile görme siniri boyunca beyne ulaşmaktadır (Morgan, 2011, s. 225). Görsel uyarıcılardan biri olan 1şı̆̆ın dalga boyu 400 ile 700 nanometre arasında kalan elektromanyetik 1şık dalgasıdır. Bu dalga boyuna göre ışık dört temel renk hissini oluşturmaktadır. Bu dört temel renk hissi kırmızı, sarı, yeşil ve mavidir. Örneğin,700 nanometre dalga boyundaki ışık, parlak kırmızı renk görünürken, sarı rengi oluşturan dalga boyu 600 nanometre civarındadır (Hoeksema vd., 2009, s. 130; Krishna, 2016, s. 31). İnsan beyni dış dünyayı birer resim olarak algiladığından görmenin temsil yeteneği açısından görsel hafıza ile daha ilişkili olduğu sonucuna varılmaktadır (Barat, 2007, s. 340). Bu, marka iletişimi çalışmalarında görme duyusunun sıklıkla kullanılmasının gerekçesini ortaya koymaktadır. Tüketici araştırmalarına göre alışveriş aktivitelerinin \%80'e yakını görsel uyarıcılar olan logo, ambalaj, renk, parlaklık ve tasarım unsurları ile gerçekleştirilmektedir. Uyanık olunan her an en fazla maruz kalının duyu olması açısından görme duyusu, markalar için de etkisine en fazla inanılan uyaran şeklidir (Sayadi, Mobarakabadi ve Hamidi, 2015, s. 101-102).

Görme duyusu ile yakından ilişkili olan ve çokça birlikte kullanılan diğer bir duyu işitme duyusudur. Birlikte kullanılması uyanııların beyne iletilmesi esnasında benzer süreçlerden geçmesinden kaynaklanmaktadır. Görme duyusundan farkı, uyarıcıların elektromanyetik dalgalar ile değil ses dalgaları yoluyla iletilmesidir. Mekanik bir titreşim ile çevreden gelen uyarıcılar işitsel alıcılara sinir akımı yoluyla iletilmektedir (Duizer, 2001, s. 18). Dış çevreden gelen işitsel uyarıcılar orta kulak vasıtasıyla baziler membran denilen kısmın titreşmesine neden olmaktadır (Meilgaard, Civille ve Carr, 1999, s. 35). Görme duyusuna benzer şekilde işitsel sistemde de seslerin algılanması $20 \mathrm{~Hz}$ (saniyede devir) ile $20.000 \mathrm{~Hz}$ arasında gerçekleşmektedir. Örneğin sesi seviyesi, yoğunluğu, şiddeti veya temposu sesin uyarılma düzeyini belirlemektedir. Çünkü bu tip uyarılma kan basıncı, kalp atış hızı ve solunum hızı gibi fizyolojik belirtilere 
paralel olarak gerçekleşmektedir (Brugge, 1988, s. 4; Kellaris ve Kent, 1993, s. 384-385). Sesin tüketici davranışlarını yönlendirmede motivasyonel bir güce sahip olmasının temel nedeni ise ruh hali, psikolojik durumun, duyguları etkileyerek tercih ve yargılar üzerindeki etkisinden kaynaklanmaktadır. Marka iletişim çalısmalarının \%41'nin işitsel öğelere dayandırılması bu etkinin gerekçesini ortaya koymaktadır (Sayadi vd., 2015, s. 101-102).

Görme ve işitme duyu ikilisinde bulunan çalşma prensibi benzerliği, koku ve tat duyularında da kendini göstermektedir. Bunun temel nedeni koku ve tat duyularının her ikisinin de kimyasal duyu sınıflandırmasında bulunmasıdır. Kimyasal uyaranlara yanıt veren duyusal bir süreç olan koku (Mozell, 1988, s. 59), moleküler yapıların uyarılmayı sağlaması ile gerçekleşmektedir (Morgan, 2011, s. 237). Bu işleyiş içerisinde koku alma hücreleri her iki veya üç gün içerisinde yenilenirken, olgunlaşan hücreler yok olarak yerini yeni hücrelere bırakırlar (Cüceloğlu, 2006, s. 105-106). Dı̧̧ çevre uyaranlarının koku alma epitelyumunda tespitinde her burun deliğinin farklı bir epitelyumu devreye girmektedir. Tahminlere göre ise insanoğlu yaklaşı 10.000 kadar farklı kimyasalı tanıyabilmektedir (Stevenson ve Boakes, 2004, s. 69; Buck, 2004, s. 117; Bradford ve Desrochers, 2009, s. 141). Kokusal ipuçlarını yaratan koku uyaranlanı, diğer duyuların işleyiş prensibinde olan Talamus'tan ${ }^{3}$ geçmeyip doğrudan beynin limbik ${ }^{4}$ sistemindeki hipokampüs'e ${ }^{5}$ geçmektedir. Bu da koku duyusunun en ilkel duyu birimi olmasını sağlamıştır. Doğrudan limbik sisteme bağlanması kokunun duygusal tepkilerle olan yakın ilişkisini de açıklar niteliktedir. Görme, işitme gibi daha bilişsel olan duyuların yanında koku duyusu, duygu yoğun tepkilere neden olması bakımından marka iletişiminde oldukça önemli bir konumdadır (Herrmann, Zidansek, Sprott ve Spangenberg, 2013, s. 32; Ozan, 2017, s. 277-278). Örneğin ortam kokularının hoşluğu veya tatsızlı̆̆ ürün değerlendirmesinde duygusal tepkilere neden olurken (Bosmans, 2006, s. 33) iştahı yöneten sinir hücreleri koku duyusu ile birlikte işlediğinden koku ve tat ikilisi lezzet deneyiminin ortaya çıkmasında öncelikli rol üstlenmektedirler (Stephens, 2017, s. 85).

Diğer bir kimyasal duyu olan tat duyusu, dil üzerinde bulunan alıcıların uyarılması ile işlemektedir (Stevenson ve Boakes, 2004, s. 69). Ağız içerisindeki dört ayrı alanda bulunan tat tomurcuklar1 50 ile 100 hücreden oluşan tat alma epitelyum hücreleri 6 ile 8 günde bir yenilenmektedir (Frank, Hettinger ve Mott, 1992, s. 374-376; Meilgaard vd., 1999, s. 34). Tat tomurcukları tatlı, tuzlu, ekşi, acı ve lezzetli anlamına gelen umami tat tomurcukları olarak beş temel tat hissine sahiptir (Stevenson ve Boakes, 2004, s. 69). Söz konusu tat hisleri ise dil yüzeyinde eşit dağglım göstermemektedir. Dil arkasında bulunan tat tomurcukları ac1 maddelere, dil ucu tatlı maddelere, dil yanları ekşi maddelere, dil kenarları ise tuzlu maddelere daha duyarlıdır (Beidler, 1988, s. 124). Markalar açısından bakıldığında marka iletişimi çalışmalarının \%31'nin tat içeren lezzet algısından oluştuğu görülmektedir. Bu da tat algısının tıpkı görsel uyarıcılardaki logo, işitsel uyarıcılardaki jenerik müziğin marka kimliğine dönüşebilmesi gibi tat imzası olarak bir kimlik göstergesi olabileceğinin açık bir kanıtıdır (Sayadi vd., 2015, s. 102).

Deri ile doğrudan temas ve vücut hareketlerinin dış dünyaya göre pozisyonunu açıklayan vücut hareketleri dokunma ve denge duyularını oluşturmaktadır (Mather, 2018, s. 18). Dış dünya ile en temel temas şeklini açıklayan dokunma duyusu, deri ve dokunma alıcılarını içermektedir. İnsan derisinin 100 milimetre karesinde her biri yaklaşık 640.000 mikro alıcı bulunan sinirlere bağlı 50 alıcı bulunmaktadır (Lindstrom, 2007, s. 38). Yetişkin bir erkek baz alındığında, vücut yapısının \%16-18’ine denk gelecek şekilde yaklaşı1k 18.000 santimetrekare deriye sahip olduğu söylenebilmektedir (Gallace ve Spence, 2010, s. 246-247). Dış dünya ile en sıcak temasa aracilık eden dokunma duyusu ile diş yüzeyler hakkında (sıcak, soğuk, sert, yumuşak vb.), bilgiler elde edilmektedir (Mather, 2018, s. 61). Sevgi ve sicaklık ile bağdaştırıldığından yakın duyu olarak da adlandırılan dokunma duyusu, marka iletişim çalışmalarının $\% 25$ 'inde kullanılmaktadır. Dokunma deneyimi ile ürün hakkında deneyim sahibi olabilme tüketici davranışlarını yönlendirmesi açısından önem taşımaktadır (Hornik, 1992, s. 449; Peck, 2009, s. 18; Sayadi vd., 2015, s. 101).

Bedenin dış dünyaya karşı duruş pozisyonunu yansıtan denge duyusu yer çekimine göre vücudun nasıl bir pozisyonda bulunduğunu ve bedenin bu duruş şeklinden nasıl etkilendiğini ortaya koymaktadır

\footnotetext{
${ }^{3}$ Her bir duyu organından gelen uyarıcıları alarak sinyalleri, ilgili beyin kabuğuna iletmektedir. Örneğin, işitme ile ilgili sinyallerin işitme ile ilgili beyin kabuğu bölgesine iletilmesinden thalamus sorumludur.

${ }^{4}$ Limbik sistem olarak da adlandırılan orta beyin, temel işleyiş itibari ile yiyecek, içecek ve cinsellik gibi motivasyonel davranışların yanı sıra korku, heyecan, saldırganlık gibi duygusal davranışları organize etmektedir ve beyin kimyasallarının bir çoğunu üretmekten sorumludur.

${ }^{5}$ Hipokampüs, duygular, anılar ve belleğin bulunduğu kısımdır. Beyin yapısında kalıcı depolamayı sağlayarak anıları kurtarmadan ve öğrenmenin gerçekleşmesinden sorumludur.
} 
(Cüceloğlu, 2006, s. 72). Merkezi beyincik olan denge duyusu, kulaktaki yarım daire kanalları ile vestibüler torbackklarda bedenin denge durumunu ortaya koymaktadır. Denge duyusu kulak işlevleri arasında görünse de ayrı bir alıcı pozisyonunda olduğundan bedenin denge durumunu ifade etmek için kullanılmaktadır (Ertürk, 2017, s. 206).

Görüldüğü üzere literatürde beş duyu olarak geçse de kaynaklar denge duyusunu da işin içine katarak toplamda 6 duyudan bahsetmektedir. Bunlardan ilk ikisi görme ve işitme ikilisi, diğer ikili kimyasal duyular olan koklama ve tatma, son ikili ise vücut duyuları olarak ifade edilen dokunma ve denge duyularıdır. Tüketici tutumları ve marka algısı açısından bakıldığında ise 6 değil 5 duyusal uyarıcıyı oluşturan görme, işitme, koklama, dokunma ve tatma duyularından faydalanıldığı görülmektedir.

\section{Beş Duyu Özelinde Stratejinin Kurulumu}

Markalar, tüketici algılarını kendi lehlerine çevirmek ve bunu sürdürülebilir kılmak için çok çeşitli stratejiler gütmektedir. Markalama çalışmaları ve farklılaşmanın en önemli nedeni ise rekabettir. Bu açıdan bakıldığında markaların tüketiciler için fayda ve teklif sunmaya çabaladıkları bilinmektedir. Değerli mülk, donanım, araçlar gibi maddi kaynaklar oldukça önemlidir. Ancak bundan daha önemlisi imaj, itibar ve alg1 gibi maddi olmayan kaynaklara dayalıdır. Çünkü tüketici algıları en az fiyat-perfomans kadar algısal gerçekliğe itibar etmektedir. Örneğin, Coca Cola markasının ismi birçok ülkenin gayri safi milli hasılasından daha değerlidir. Bunun ise temel nedeni Coca Cola'nın maddi olmayan kaynaklara verdiği önem ve bunun tüketicide bulduğu karşl1ıtır (Wilson ve Gilligan, 2005, s. 505).

Tüketici algılarının yönlendirilmesinde fonksiyonel fayda unsurları, sürdürülebilirlik ve faklılaşma açısından bir takım sınırlılıklara sahiptir. Ancak buna karşın duygu ve düşünceye yönelik uyaranlar ise tutum olumuşunda daha etkin bir yere sahiptir. Markalar çeşitli stratejilerle tüketici algisından fonksiyonel, duygusal ve psikolojik bütünlük yaratmaya çalışmaktadırlar. Bu stratejilerden birisi de duyusal girdilerin temel kaynak olduğu duyu stratejisidir. Tüketicilerin duyularına seslenerek, marka algilarını yönlendiren markalar duyusal markalama modeline odaklanmaya başlamışlardır (Büdün, 2020, s. 44). Duyusal markalamanın amacı ise temelde beş duyu organı kullanılarak edinilen bilgilerin markaya yönelik girişimler ile tüketiciler için anlamlı hale getirilmesini sağlamaktır.

Duyusal markalama stratejisi beş duyu temel alınarak gerçekleştirilen bir markalama türüdür. Bu beş duyunun her biri kendi duyu özelinde kullanılarak farklılaşma elde edilmeye çalışılmaktadır. Örneğin görsel uyarıcılar dış dünyayı algılamada en fazla kullanılan duyudur. Çünkü gün içerisinde maruz kalınan görsel uyarıcılar diğer tüm uyarıcılardan çok daha fazladır. Görme çoklu duyusal etkileşimin en fazla olduğu duyu olduğu için en çok kullanılan duyudur. Çünkü renk, şekil, grafik, ışık, parlaklık gibi görsel uyarıcıların insan doğası üzerindeki rolü oldukça fazladır. Bunların yanı sıra görme duyusu ile böbreküstü bezleri aktive edilerek tüketicilerde tat tomurcuklarını uyarmaktadır. Bu da görme ile tat-lezzet arasında güçlü ilişki ile yiyecek seçiminde güçlü bir aktör olduğunun göstergesidir (Vietoris, 2017, s. 15-16). Aydınlatma/ışık veya parlaklık da tüketiciler için oldukça güçlü bir uyarıcıdır. Çünkü hoşlanma, beğenme, sevme gibi olumlu duygu durumlarını yaratmada oldukça etkilidir. Özellikle de parlaklığın tüketicileri dokunsal temasa teşvik etmesi önemli bir uyanc1 olduğunun bir göstergesidir (Decre ve Cloonan, 2019, s. 118). Diğer bir görsel uyarıcı tüketici tepkilerinde oldukça etkili olan renktir. Yıllar boyu yapılan fiziksel ve psikolojik araştırmalar, ürünler, mağaza içi dekorasyon, reklam ve diğer görsel alanlarda kullanılan rengin tüketici tercihlerindeki önemini ortaya koymuştur (Crowley, 1993, s. 59). Renk uyarıcısının tüketici psikolojisinde bu denli önemli olmasının asıl nedeni ise duygu ve davranışlar üzerindeki etkisidir. Renkler arasında tercih yaparken de oldukça dikkatli olunmalıdır. Çünkü tüm renkler gözün aynı renk spektrumunda bulunmamaktadır. Örneğin, kırmızı renk sıcak ve yüksek dalga boyuna sahipken, mavi renk soğuk ve düşük renk boyuna sahiptir. Markalar açısından bir değerlendirme yapıldığında ise kırmızı satış, mavi kurum rengidir. Bu nedenle de Coca Cola kırmızı, IBM ise mavi renkte konumlandırılmıştır (Ries ve Ries, 2019, s. 127-128; Chebat ve Morrin, 2007, s. 190). Diğer bir görsel uyarıcı logo ve amblemdir. Her şeklin insan beyni tarafından alınması ve algılanışı farklı olduğu için logonun şekli de oldukça önemlidir. Örneğin kendine özgü renklerle (kırmızı ve sarı) oluşturulan deniz kabuğu amblemi Shell'i, uçan mavi kuş ise Twitter'ı çağrıştıran başarılı duyusal tasarımlardır (Ries ve Ries, 2019, s. 121, 127-128). Yine ambalaj, mağaza çevresi, mağaza tavan yükseklĭği, vitrin, satıs noktası ve diğer tüm görsel uyarıcılar tüketici davranışlarını etkileyen önemli unsurlardır. Bu açıdan tüketiciyi mağazaya çekmek için etkili birer stratejidirler (Mower, Kim ve Childs, 2012, s. 442-443). 
İşitsel uyarıcılar, marka iletişimi çalışmalarında oldukça yoğun kullanılan ve bilinçaltını etkileyen önemli bir duyudur. İnsan beynini aktive ederek bilinçsiz arzuların açığa çıkmasını sağlayan işitsel uyaranlar, oldukça etkili bir fenomendir. Yapılan araştırmalar, görsel içeriğin göz ardı edildiği noktada işitsel bilginin ürün içeriğinden beş kat daha fazla etkili olduğunu ortaya koymuştur (Vietoris, 2017, s. 17). Markalara ses ile kimlik kazandırlmasının temel amacı, tüketicilerde duygusal tepkilere yol açarak, insan zihnine, duygularına ve davranışlarına nüfuz etmektir (Lancu, Bara, Seserman ve Bindea, 2009, s. 102-104; Gustafsson, 2015, s. 20-21). Örneğin, Intel’in dört notalı imza sesi ile tüketicilerde Intel'e ilişkin bilgi, duygu ve deneyimlerin tamamı hatırlatılmaktadır (Stephens, 2017, s. 83-84). Gündelik hayatın her aşamasında mağaza, ofis, asansör, film, reklam vb. alanlarla kullanılan arka fon müziği dinleyicilerde duygusal bir tepki ortaya çıkarmak için kullanılmaktadır (Kellaris ve Kent, 1993, s. 381-383). Yine müziğin temposu tüketici tercihlerini etkileyen önemli bir işitsel uyarıcıdır. Uyarılma açısından hızlı ve yavaş tempolu müzikler tüketici tepkilerinde farklılıklara neden olmaktadır. Örneğin süpermarketlerde yavaş tempolu müziklerle müşterilerin mağazada daha fazla vakit geçirerek daha fazla alışveriş yapması amaçlanırken fast food mağazalarında tempolu müziklerle yemeklerin hızlı yenilip iş akışının hızlı olması amaçlanmaktadır (Alpert, Alpert ve Maltz, 2005, s. 371; Berman, Evans, ve Chatterjee 2013, s. 495-496). Diğer taraftan seçilen reklam müziği reklam içeriğine uyduğu oranda tüketici dikkatinin de artarak ürüne yönelik tanıma ve hatırlama işlevlerini arttırdığ1 gözlenmiştir (MacInnis ve Park, 1991, s. 164,172). Dolayısıyla müziğin yalnızca duygusal tepkilere değil bilişsel bir takım sonuçlarının da olduğu görülmüştür.

Yaklaşık 10 bin kadar kokuyu ayırt edebilen insanoğlunun bireysel olarak kodlanmış genetik bir kokusu bulunmaktadır (Axel, 1995, s. 69). Dış çevreden alınan koku girdilerinin algılanması ise diğer duyusal uyarıcılara göre daha uzun sürmektedir. Örneğin görsel uyarıcıların algılanması 45 milisaniye (saniyenin binde biri) iken, koku uyarıcılarının algılanması yaklaşık 450 milisaniyedir. Bunun nedeni koku nöronlarının beyindeki ilgili sisteme daha geç ve yavaş iletilmesidir (Morrin, 2009, s. 78). Koku duyusunun bilinçli bir şekilde sonlandırılması veya kapatılması gibi bir durum söz konusu değildir. Anında duygusal tepkilerin kaynağı olan koku ipuçları kimyasal uyarı sisteminin aktive edilmesiyle engellenemez reaksiyonlara neden olması bakımından marka iletişimi çalışmalarında sıklıkla kullanılmaktadır (Bradford ve Desrochers, 2009, s. 142). Duygusal tepki olan uyarlma ile birey, hoşa giden ve beğenilen bir kokuya yaklaşırken, tersi durumda aktif bir kaçma davranışı gerçekleştirmektedir. Çünkü uyarılma bireyi fizyolojik bir duygu durumuna teşvik etmektedir. Duygulara en yakın duyu olarak bilinen koku, her tüketicide aynı tepkiye neden olmamaktadır. Çünkü koku ipuçları, örtük veya bilinçaltı nedenlere bağılı olarak işlemekte ve tüketici farkındalı̆ı olmadan da otomatik tepkilere neden olabilmektedir (Rimkute, Moraes ve Ferreira, 2015, s. 30). Bu nedenle kokunun, otobiyografik hafiza ve anılar gibi geçmişe dönük tecrübeleri hatırlatan güçlü bir etkisi vardır.

Dokunma duyusu diğer tüm duyulardan farklı olarak cilt yüzeyinin bilinçli bir hissetme yeteneğini kapsamaktadır. $\mathrm{Bu}$ bilinçli hissetme yeteneği herhangi bir nesneye ilişkin fiziksel bir teması gerektirmektedir (Medway, 2014, s. 203; Montagu, 1971, s. 17). Dokunsal girdiler, ürünler ilgili (sıcaklık, pürüzlülük, ağıllık vb.) özelliklerin değerlendirilmesini sağladığı için tanısaldırlar. Ürüne ilişkin güven duygusu gelişiminde veya dokunmaktan hoşlanan tüketicilerin markaya yönelmesinde dokunsal öğeler oldukça önemlidir (Grohmann, Spangenberg ve Sprott, 2007, s. 238; Peck ve Childers 2003a, s. 440; 2003b, s. 46). Tüketiciler açısından bakıldığında dokunmanın iki tür amacı olduğu bilinmektedir. Bunlardan ilki ürün hakkında bilgi sahibi olmak ikincisi ise hedonik duygusal deneyimler yaşamaktır. Ürün özelliklerinin saptanması tüketiciler için kalite algısının sorgulanmasına aracılık ederken (Lindstrom, 2017, s. 148-149), hedonik deneyim yaşamak isteyen tüketiciler, dokunmanın onlara iyi geleceğine ve onları daha iyi hissettireceğine inanmaktadır. Bunun haricinde pürüzlülükle ilgili yapılan çalışmalar, pürüzlü alanların kişileri daha az hoşnut hissettirdiğini, pürüzsüz alanların ise tüketiciler tarafindan daha hoş algılandığını ortaya koymuştur (Klatzky ve Peck, 2012, s. 139-140; Peck ve Shu, 2009, s. 434). Dokunma hissinin yarattığ1 psikolojik yönelim paket veya sunumların tüketicilerde yarattı̆̆ izlenimleri yönetmede de başrol oynamaktadır. Öyle ki plastik bir şişeden ziyade cam şişelerin tercih edilmesi buna örnek olarak gösterilebilir. Coca Cola'nın çoklu duyusal deneyim sağlayan şişe tasarımı veya silindir bir karton kutuda sunulan Pringles cipsleri, dokunarak iyi hisseden tüketici kitlesine yönelik önemli girişimler olarak görülmektedir (Vietoris, 2017, s. 19). Buradan yola çıarak dokunma duyusuna yönelik gerçekleştirilen araştırmalara ilişkin bir genelleme yapılacak olunursa, dokunsal girdi ve marka algisı arasında güçlü bir bağlantı olduğu ve ürün değerlendirmelerini yüksek oranda etkilediği söylenebilir.

Diğer tüm duyusal uyarıcılar çoğunlukla tek başına da işleyebilen özelliğe sahipken tat duyusu genellikle lezzet elde edilecek gıda ile ilgili ortamdaki diğer tüm uyarıcılardan doğrudan etkilenmektedir. Bir 
yemek sırasında tat uyaranları en son algılanır ve lezzet denilen unsurun ortaya çıkmasına aracilık eder. Ancak toplam tat deneyimi noktasında bakıldığında bir yemeğin sunulduğu kap, gıda ürünün kendi çıkardığ1 sesin, yemeğin kokusunun gibi diğer tüm uyarıcılar tat tomurcuklarından gelen hissi destekleyerek lezzet algısını ortaya çıkardığı bilimsel olarak kanıtlanmış bir gerçektir. Çünkü tat duyusu diğer duyusal girdiler ile koordineli şekilde çalışmaktadır. Örneğin bir yemeğin kokusu beğenilmediğinde veya görüntüsü iştah açıcı değilse o gıda ürünü tadına bakılma şansını da otomatik olarak kaybetmektedir (Vietoris, 2017, s. 22; Elder ve Krishna, 2010, s. 748-750). Yine görsel işaretlerden olan renk, ürün kalitesi ile ilgili ipuçları vermesi bakımından tüketici değerlendirmelerini etkilemektedir (Hoegg ve Alba, 2007, s. 491). Öte yandan gıda ürünün örneğin patates cipsin 1sırıldığında çıkardığı ses cipsin tazeliği ve gevrekliğinin bir göstergesi olarak algılanmakta ve tüketici kararlanını etkileyebilmektedir. Yapılan araştırmalar, bir gıda maddesi tüketiminde çıkan ses ile tat alg1sı arasındaki bağlantının paralel olduğunu ve ses ne kadar yüksekse tüketicilerde tazelik algısının o denli fazla olduğunu ortaya koymuştur. Yine dokunma ve tat etkileşiminde ürüne/gıda maddesine dokunma ihtiyacı duyan bireylerin tat algisına ilişkin daha olumlu değerlendirmeler yaptıkları saptanmıştır (Dematte vd., 2014, s. 58; Krishna ve Elder, 2009, s. 285). Söz konusu dokunma deneyiminin psikolojik uyarılmadan ziyade fizyolojik tepkiye yani bilişsel bilgi edinme, yargi gibi eylemleri beslediği söylenebilir (Robinson, Blissett ve Higgs, 2013, s. 101).

Görüldüğü üzere tüketicilerin herhangi bir marka algıları, duyusal uyarıcılar vasıtasıyla görme, işitme, koklama, dokunma ve tatma duyuları ile şekillenmektedir. Markaların, tüketici alg1 ve tutumlarını kendilerine yöneltmek ve bunu sürdürülebilir kılmak en temel amaçlardandır. Ancak duyusal markalama stratejisinde beş duyuya ilişkin algısal yönelimin ve bu yönelimin hangi tutum öğesi odaklı konumlandırıldığı oldukça önemlidir. Çünkü markaların tüketicilere sundukları ürün veya hizmetlerin özelliklerine göre duyusal uyarıcıları tercih etmeleri, stratejinin başarısını etkileyecek en önemli bileşendir.

\section{Duyusal Markalamada Alg1 ve Tutumların İşlevi}

Bireyler, görme, işitme, koklama, dokunma ve tatma duyuları sayesinde dış çevre hakkında bilgi sahibi olup, bunları anlamlandırabilmekte ve etrafında neler olup bittiğinin farkına varmaktadır. Dış dünya hakkındaki anlamlandırma ile bir iğnenin batma hissi, limonun ekși tadı veya bir müziğin sesi ile ilgili temel deneyimler elde edilmektedir. Duyumların ilkel doğası, nesne, olay, olgu ve kavramların anlamlandırılması algisal süreç ile mümkündür (Mather, 2011, s. 17). Örneğin bir market reyonunda bulunan deterjanın ambalajından veya kokusundan hangi tip giysiler için kullanılacağının anlaşılması fiziksel ve bilişsel algılama süreçlerinin bir sonucudur (Hoyer, MacInnis ve Pieters, 2012, s. 80). Alg1lama süreci maruz kalınan duyusal girdinin türüne göre değişkenlik göstermektedir. Çünkü dış dünyadan gelen girdiler beş duyu vasitasıyla alınabilmektedir. Söz konusu bu duyusal girdilerin anlamlı birer yorumlamaya dönüşmesi tamamı ile içsel ve öznel bir değerlendirme ile mümkündür (Krishna ve Elder, 2009, s. 283; Solomon, Bamossy, Askegaard ve Hogg, 2006, s. 39, 50). Bu değerlendirme içinse dış çevre uyaranlarına maruz kalmak gerekmektedir. Bu uyaranlar arasından hangisinin anlamlandırılacağına dair seçici dikkat ile yorumlama algilama süreci olarak ifade edilmektedir (Solomon, 2017, s. 108; Schiffman ve Wisenblit, 2015, s. 116).

Algilama sürecinde bireyler dış dünyadan elde ettikleri bilgileri, bellekleri ile karşılaştırarak bir ürün veya marka ile ilgili değerlendirme yapmakta ve nihai karar vermektedirler (Peck ve Childers, 2008, s. 194). Söz konusu bu değerlendirme, bir nesne veya marka ile ilgili yüksek ve düşük yorumlama şeklinde gerçekleşmektedir. Bu yorumlama yüksek yorumlama şeklinde ise olumlu, düşük yorumlama şeklinde ise olumsuz duyusal algiyı temsil etmektedir. Bilişsel psikolojiye göre olumlu duyusal algilama genellikle hızlı, otomatik ve zahmetsizken, olumsuz duyusal algılama yavaş, bilinçli ve zahmetlidir (Haase, Wiedmann ve Labenz, 2018, s. 566). Tüketiciler diş çevrede yer alan herhangi bir nesne ile ilgili tercih etme veya etmeme üzerine belli bir tutum sahibidirler. Örneğin, Lancome kozmetik markasına karşı olumlu tutum benimseyen bir tüketicinin, söz konusu markayı koruması, sahiplenmesi ve ürünlerini kullanması beklenmektedir. $\mathrm{Bu}$ olumlu tutumun temel nedeni ise genellikle söz konusu markaya ilisskin tüketicinin önceden oluşmuş olumlu deneyimleridir (Moye ve Kincade, 2003, s. 59-59). Dış çevre uyaranlarını algılama biçimi büyük ölçüde tüketicilerin tutumlarını da şekillendirmektedir. Çünkü tutumlar, tüketici deneyimleri sonucu elde edilen bilgi düzeyi ve bu bilgi düzeyinin ortaya çıardığı görüss, inanış ve yargisal ifade bütünüdür. Söz konusu deneyimler ise ya bireysel tecrübe şeklinde ya da toplumsallaşmanın sonucunda ortaya çıkmaktadır (Sullivan, Hartley, Saunders, Montgomery ve Fiske 1994, s. 18). Ancak her ne şekilde olursa olsun belli bir tutum oluşumunda aşağıda aktarılan tutum öğelerinde (bilişsel, duygusal, davranışsal) koordineli, istikrarlı ve dengeli bir bütünleşme sağlanması gerekmektedir. 
Tüketici davranışlarının temelinde bilişsel, duygusal ve davranışsal tepkiler yer almaktadır. Söz konusu bu tepkilerin bir araya gelmesi ile ortaya çıkan tavır ve duruş, tutum olarak ifade edilmektedir (Kardes, Cronley ve Cline, 2010, s. 10-11). Algılama biçimindeki olumlu veya olumsuz değerlendirme, tutum nesnesine yönelik biliş, duygu veya eylem düzeyinde gerçeklemiş olabilir. Nitekim tutumlar sübjektif ve biricik olma özelliğini taşımaktadırlar (Boone ve Kurtz, 2011, s. 152). Öte yandan tutumların sürekliliği tutum nesnesine yönelik olumlu görüşün veya deneyimin devamlılı̆ına bağlıdır. Öyle ki herhangi bir tutum nesnesine karşı olumlu görüşe sahip olan tüketiciler, yine aynı tutum nesnesi ile ilgili olumsuz bir deneyim yaşadıkları takdirde olumlu algısal değerlendirme görece olarak olumsuz yargı boyutuna taşınabilmektedir (Dick, 1994, s. 101). Bilişsel boyutla verilen tepkiler, alg1 ve düşüncelere dayanan inanç ve bilgiler bütünüdür. Duygusal boyutta ise tutum nesnesine ilişkin verilen duygusal tepkiler öne çıkmaktadır. Tutum nesnesine yöneltilen eylem durumu ise davranışsal boyutun göstergesidir (İnceoğlu, 2011, s. 30; Solomon vd., 2006, s. 140). Tüketici motivasyonlanına ilişkin yapılan araştırmalarda diğer etkenlerle karşılaştırıldığında bilişsel değerlendirmelerin çok daha etkili olduğu belirlenmiştir. Ürün değerlendirmelerinde alternatifler arasından en rasyonel seçimi yapmak, mantıksal çıkarımlar ile ihtiyacı karşılaması doğru orantılıdır (Morschett, Swoboda ve Foscht, 2005, s. 428). Tüketicilerin algılarını yöneterek olumlu tutum geliştirme çabasında olan markalar için tüketici duyguları önemli bir referans noktasıdır. Duygusal deneyim ile tüketicileri yönlendiren en iyi örnek Disney markasıdır. Tema parklar ile tam bir eğlence deneyimi yaratan marka, tüketicileri etkilemeyi başarmıştır (Travis, 2000, s. 79). Uyaranlara verilen duygusal tepkiler genellikle otomatik ve bilinç dışı gerçekleşmektedir. Duygusal öğeler ile marka ile bağ kurulması uzun dönemli ilişki kurabilmenin öncelikli koşulları arasında sayılmaktadır. Bu koşulları yerine getirmek içinse markaya uygun duyusal tercihin yapılması gerekmektedir. Örneğin bir marka eşsiz şekilde dizayn edilmiş logosu ve rengi ile öne çıkmak isterken, bir marka jenerik müziği ile bir başkası tadı ile öne çımak isteyebilir. (Sharifi, 2014, s. 44; Klink, 2003, s. 144). Başka bir marka ise çoklu duyusal stratejiyi benimseyerek beş duyudan en az üç veya dördünü baz alarak bir duyusal markalama stratejisi kurgulayabilir. Örneğin ürün olarak kahve satan bir mağaza, hem kahvenin tadı, hem çevreye yaydığ1 kokusu, hem mağazada çalan müzik tınısı ile markalama yapabilir. Bu tamamen markanın kendi tercihine bağılır. Psikoloji bilimine göre insan davranışlarını anlamlandırılabilmenin temel koşulu insan duygularını anlamaktan geçmektedir. Çünkü insanlar yaşamları boyunca dış çevre ile yakın etkileşim kurarak, sürekli deneyim sahibi olmaktadır. Bu da zamanla otomatik duygusal tepkilere neden olmaktadır. Duygusal tepki vermek için gereken deneyim, bireylerin tutum nesnesine ilişkin olumlu veya olumsuz bir değerlendirme yapmalarını sağlamaktadır. Tutum nesnesinden elde edilen memnuniyet veya memnuniyetsizlik duygusal tepkilere neden olduğu için bunların eyleme dönüşmesi de güçlü bir olasilıktır (Lazarus, 1991, s. 104; Wanke, 2008, s. 8). Tüketici davranışları duyguların bireyleri irrasyonel şekilde yönlendirmesiyle anlam kazanmaktadır. Düşünce ve fikri temsil eden bilişsel düzey ile duygular çeliştiğinde çoğunlukla kazanan taraf duygular olmakta ve davranışta bu yönde ortaya çıkmaktadır. Rasyonel yargıların davranışa dönüşme ihtimali çok daha fazla görünse de genelde duygular baskın gelerek eyleme dönüşme ihtimali çok daha fazla olmaktadır (Gordon, 2006, s. 9). Tüketiciler ürünle ilgili beklenti düzeylerini vaat edilen değerler doğrultusunda oluşturmaktadıllar. Markanın ilettiği mesajlar ile vaatleri ve tüketici ilgilenim düzeyi tutumların da yönünü belirlemektedir. Öyle ki yüksek ilgilenim düzeyindeki bir tüketici bilişsel davranışlarını bilişsel boyutlarda gerçekleştirirken düşük ilgilenim düzeyindeki tüketiciler duygusal iletilere daha eğilimlidir (Van Dyck, 2017, s. 101-102). Markaların tüketicilere sunduklar1 ürün ve hizmetlerde duyusal temas noktalarını belirlemesi ile tüketici ilgilenim düzeyleri belirlenebilmektedir. Örneğin Coca Cola, gazlı içecek sektöründeki lider konumunu ürüne yüklediği sembolik değerler ile yeniden üretmektedir. Rakipler arasından renk, ses, koku, doku ve tat ile ayrışan markalar yaratmak mümkündür.

\section{Marka Algısının Temel Bileşenleri}

Markaların, tüketiciler ile duyusal temas noktaları belirlemesi, algyya yönelik olumlu bir sinerji ile mesajları iletmenin önemli bir yoludur. Markanın hedef kitlelere sunduğu ürün veya hizmetin niteliği ne olursa olsun tek gerçeklik, nasıl algılandığı ile ortaya konulan gerçekliktir. Dolayısıyla marka iletişiminde duyusal temas noktaları oldukça önemlidir (Lindstrom, 2007, s. 115-116). Tüketicilerin herhangi bir markaya ilişkin algıları, uzun dönemdir tüketici araştırmalarına konu olmuştur. Tüketicilerin marka ile ilgili algiları, doğrudan markanın sunduğu ürün veya hizmetlerle ilgili olan veya olmayan nitelikler, fonksiyonlar, faydalar, kişilik özellikleri ve kimlik özellikleri gibi pek çok zihinsel temsilden oluşmaktadır. Bu nedenle tüketicilerin, markaya ilişkin olumlu veya olumsuz değerlendirmelerinin tümünü kapsamaktadır (Keller, 2016, s. 8; Keller, 2003, s. 596). 
Marka algısına yönelik alan yazın tarandığında marka algısının karşılığı olarak marka değeri/denkliği veya müşteri tabanlı marka değeri kavramlarının kullanıldığı görülmüştür. Bu çalışmada da marka algısı, bir markanın isim, logo veya sembolünün, ürün veya hizmetlerin tüketicilerine sağladığı değeri ifade eden marka denkliği kavramı aktarılmıştır. Marka denkliği boyutları olan marka bilinirliği, algılanan kalite, marka çağrışımları ve marka sadakati de marka algısının oluşmasındaki temel bileşenler olarak ele alınmıştır (Aaker, 1991, s. 27; Motameni ve Shahrokhi, 1998, s. 276).

Marka bilinirliği, tüketicilerin herhangi bir ürüne ihtiyaç duydukları anda çok sayıda marka ve mağaza arasından tanıdık, bildik olana yönelmeleridir. Özellikle tüketiciler satın alacakları ürün veya hizmetle ilgili kararsız kaldıklarında genellikle aşina oldukları isme, logoya yönelmektedirler. Bilinirlik, tüketicilere kalite algısı ve güvenirlik gibi soyut değerleri çağrıştırdığından tercihlerle oldukça etkili olan bir unsurdur. Bilinirlik ile markaya ilişkin zihinsel şemalar geliştiren bireyler, beklentilerinin karşılanması veya karşılanmamasında önceki deneyimlerinden aşinadırlar. Tüketici zihnindeki olumlu veya olumsuz değerlendirmelerin/deneyimlerin (Alba ve Hutchinson, 1987) bir özetidir. Logo, renk, tat gibi uyarıc1 örnekleri verildiğinde tüketiciler, ilgili markaya yönelik içerikleri hafızadan geri çăğrmaktadırlar. Örneğin restorana giden bir tüketici, oradaki yiyeceklere ve yiyeceklerin tadına önceden aşina olduğu için karşılaşabilecekleri konusunda zihninde bir senaryoya sahiptir. Söz konusu senaryo markaların tüketici zihinlerine ekmeye çalışı̆̆̆ marka algısı boyutlarından marka bilinirliğidir (Aaker, 1991, s. 29; Noel, 2009, s. 110). Marka bilinirliği, bir markanın tanınıllığı ve markayı hatıllama işlevlerinden oluşmaktadır. Marka ile ilgili ipucu verildiğinde önceki maruz kalma durumu/deneyimlerden markanın akıllara gelmesi marka tanınırlığ iken, ihtiyaç durumunda ürüne ilişkin herhangi bir markanın hafızadan geri çağırılması markayı hatırlamadır. Mısır gevreği ve tahıl ürün gamında akıllara ilk gelen markanın Kellog's olması marka bilinirliğine örnek olarak verilebilir (Keller, 1993, s. 3; Aaker, 1995, s. 10-11; Vasudevan ve Kumar, 2019, s. 348; Keller, 2013, s. 73).

Marka çağrışımları, bir marka ile ilgili tüketicilerde ortaya çıkan maddi veya maddi olmayan temsilleridir. Markadan elde edilen tüm deneyimler ile beș duyuya yönelik maruz kalınan tüm uyarıcılar markaya ilişkin çağrışım unsuru olabilmektedir (Faircloth, Capella ve Alford, 2001, s. 64). Markanın piyasaya sunmuş olduğu ürün veya hizmetlere ek olarak markaya ilişkin istek, beklenti, deneyim, inanç, tutum ve diğer tüm bağlantılı ifadeler çağrışım yaratmada etkilidir. Bu bağlantılar markayı alıp tüketmeye yönelik olabileceği gibi tersi durumda kullanmamayı da teşvik edebilir. Bu nedenle çağrışım unsurları yaratacak duyusal uyarıcı seçiminde markaların, ürün veya hizmetlerine uygun tercih yapmaları gerekmektedir. Böylece olumsuz çağrışım yaratabilecek değiş̧kenler bertaraf edilebilir (Pappu, Quester ve Cooksey, 2005, s. 145; Douglas, Craig ve Nijssen, 2001, s. 109). Çağrışımlar, özellik, fayda ve tutum şeklinde gerçekleşebilir (Tuominen, 1999, s. 84). Bu anlamda önemli olan tüketicilerin, bilişsel ve duygusal tepkilerini çağrışımlar yolu ile markaya yönlendirmek ve tüketici karar süreçlerine dahil olabilmektir.

Tüketicilerin herhangi bir ürün veya hizmetten beklentilerinin karşıllğını ifade eden algılanan kalite boyutu diğer bir marka algısı bileşenidir. Nesnel kalite algısının yanında (performans, dayanıklilık, güvenirlik, vb.) markadan elde edilen deneyimin yönünü ortaya koymaktadır ve kişisel değerlendirmeler bütünüdür (Shariq, 2018, s. 319). Algılanan kalite, markanın maddi veya maddi olmayan değerleri ile ilişkilendirmede markaya yönelik çağrışım sağladığında başarılı olabilmektedir. Bu yüzden işlevsel faydaların yanında soyut ifadelerin bütüncül olarak kullanılması güçlü bir rekabetçi stratejidir (Aaker, 1995, s. 17). Dolayısıyla algılanan kalite, tüketiciyi belli bir ürünü almaya teşvik edici değer teklifi sunan ve diğer markalardan kolayca ayrışmasını sağlayan öznel değerlendirmeler sonucu elde edilmektedir.

Marka algısının son bileşeni ise marka sadakatidir. Marka sadakati, belli bir markanın sunduğu ürün ve hizmetlerin satın alınma sıklı̆̆ ve satın alınma olasılı̆̆ının süreklilik ve tutarlılık arz etmesi sonucunda gerçekleşmektedir. Tüketici ihtiyaçlarının ortaya çıkmasında alternatifler arasından tek tek değerlendirmeler yaparak karar vermekten ziyade tek bir markaya odaklanmak ve ilgili markadan satın alım gerçekleştirmek sadakatin oluştuğunun bir göstergesidir (Yi ve Jeon, 2003, s. 231; Oliver, 1999, s. 34; Fitzgibbon ve White 2004, s. 215). Diğer tüm bileşenlerde olduğu gibi belli bir markaya yönelik sadakat düzeyi de kişiden kişiye değişir. Dolayısıyla sadakat, bir markanın gelecekte de tercih edilebilir olduğuna dair derin bir taahhüttür (Yoo ve Donthu, 2001, s. 2-3). Örneğin, findık kreması satın almak isteyen bir tüketicinin diğer tüm markalar arasından bir değerlendirme yapmadan doğrudan Nutella markalı ürünü alması, o markaya yönelik derin bir bağlllı̆̆ ifade etmektedir. Tüm marka alg1sı bileşenlerinin ürün veya hizmete uygun şekilde konumlandırılması, tüketicilerin tutumlarını etkileyerek satın alma kararlarında büyük oranda etkili 
olmaktadır. Satın alma eğilimi veya kararı, marka algısı bileşenleri ve tüketicilerin bilgi, his ve davranış bütünleşmesi sonucu ortaya çıkmaktadır.

\section{Marka Algısına Yönelik Tutum Oluşumunda Duyuların Rolüne İlişkin Bir Alan Yazın Değerlendirmesi}

Çalışmanın bu bölümünde duyusal markalamanın ana kaynakları olan görme, işitme, koklama, dokunma ve tatma duyularının, marka algısı boyutları olan marka bilinirliği, marka çağrışımları, algılanan kalite ve marka sadakati yaratmada ve tüketici tutumları üzerindeki etkinliğine ilişkin bir değerlendirme yapılmışır. Söz konusu değerlendirmede kullanılan alan yazın kaynakları, marka algisı, marka bilinirliği, marka çağrışımları, algılanan kalite ve marka sadakati anahtar kelimeleri ile saptanmıss olup, çoğunlukla uluslararası indekslerce taranan kaynaklardan faydalanarak derlenmiştir.

Olumlu marka alg1sı tüketici zihinlerinde olumlu izlenim yaratarak satın alma kararlarını etkilemektedir (Chang ve Liu, 2009, s. 1688). Bu nedenle markanın gerçekte neyi temsil ettiği ve tüketiciler için ne anlam ifade ettiğ̣i duyular aracıllı̆̆yla elde edilmektedir. Beş duyu organını kullanarak duyusal hafizanın aktive edilmesi markayı rakiplerinden farklılaştırmada önemli bir güçtür. Örneğin KFC markasının tüketici algılarını etkileme düzeylerine ilişkin yapılan bir araştırmada KFC'nin beş duyudan en çok görme ve tatma duyularını kullandığı saptanmıştır. Buradan da görüleceği gibi, markalar tüketici algilarını, duyumlar ve duyusal kodlar ile çevreleyerek duyusal ifadenin zihinlerde konumlandırılmasını amaçlamaktadır (Hussain, 2014, s. 53; Hulten, 2011, s. 257). Bu da duyusal markalamanın en temel amacıdır. Duyusal markalamanın tüketici algılarında karşlık bulabilmesi ise bilinirlik, çağrışım, kalite ve sadakat boyutları ile mümkün olabilmektedir.

\section{Marka Bilinirliği Yaratmada Duyusal Uyarıcıların Tutuma Olan Etkisi}

Marka bilinirliği, markaların tüketicilere sundukları değer teklifleri, çekicilik ve kalite beklentileri gibi maddi ve maddi olmayan unsurların yerine getirilmesi ve sonucunda marka sadakatine ulaşan marka algıs1 boyutunun ilk aşamasıdır. Zihinleri meşgul eden ve tüketicilerin algısal görüntülerinin dış dünyaya yansimasidır (Simss ve Trott, 2006, s. 229; Hakala, Svensson ve Vincze, 2012, s. 441; Hsieh, 2004, s. 37). Bilinirlik genellikle tüketici zihinlerinin bilisssel yönü ile ilgili olmakla birlikte satın alma kararında oldukça etkilidir. Bu etki, tüketicileri duygusal ve davranısssal yönden de etki altına alabilmekte ve bu yönde olumlu tutum oluşumunun önünü açmaktadır (Sharifi, 2014, s. 43). Bilinirlik bu gücü ise duyusal markalama uyarıcılarının her biri özelinde kullanılarak tüketici tutumlarını belirlemektedir.

Dış uyarıcılara maruz kalma noktasında ilk karşılaşılan görüntü dış görünüştür. Bir markanın renkleri, logosu, ambalajı gibi unsurlar bilinirliğe katkı sağlamaktadır. Eşsiz kahve deneyimi sunduğunu vaat eden Starbucks logosu, beklentileri karşılayarak olumlu bilinirlik algisına katkı sağlamakta ve bu doğrultuda olumlu tutum yaratılabilmektedir. Markaların dış görünüşleri tüketici algılarını yönlendirmede etki sahibidir. Örneğin doğal, yuvarlak ve özenli bir logo daha samimi algilanmakta ve akıllarda daha kalıc1 olmaktadır (Stephens, 2017, s. 74-76; Janiszewski ve Meyvi, 2001, s. 18-19).

İşitsel uyarıcılar da tıpkı görsel uyarıcılar gibi bilinirliğe katkı sağlamaktadır. Markanın sesinden, jeneriğinden veya sloganından tanınması ve geri çağırılması oldukça yüksek olasılıktır. Öğrenciler üzerinden gerçekleştirilen bir araştırmada reklam müzikleri ile ürün içerikleri karşılaştırrlmış ve müzik-ürün etkileşimi ölçümlenmiştir. Araştırma sonucunda müziğe maruz kalan öğrenciler, bilişsel olarak markayı tanıyarak bilgi işleme süreci ile tutum arasındaki güçlü ilişkiyi ortaya koymuştur (Tom, 1990, s. 49).

Koku duyusuna yönelen uyarıcılar da güçlü birer tanınma aracıdır. Kimyasal bir duyu olması ve işleyiş açısından diğer duyularda farklı olması tüketicilerin bilinçli ya da bilinç dışı şekilde markaların alg1lanmasında duyuların önemini ortaya koymaktadır (Medway, 2014, s. 193-196). Özellikle mağazalarda kullanılan ortam kokuları, tüketici bilinçleri yönlendirmede oldukça etkilidir. Örneğin Victoria Secret veya English Home mağazalarının kendilerine has kokuları ilgili markanın tanınması ve diğer markalardan ayrilmasinda etkili bir unsurdur.

Markaların tüketicilere sundukları ambalajların şekilleri, sertlikleri, sıcaklıklanı gibi unsurlar da bilinirlik elde etmede önemli dokunsal uyarıcılardır. Örneğin Toblerone çikolatalarının üçgen karton kutusu dokunsal olarak tüketicileri markaya yönelik tutum oluşturmada ve markanın tanınırllğına katkı sunmaktadır. Bu sayede tüketiciler üçgen şekilde konumlandırılmış çikolata ambalajını diğerinden ayırabilmektedir. 
Tat duyusuna yönelik gerçekleştirilen araştırmalarda ise tüketicilerin daha önceden tadına aşina oldukları ürünlere maruz kaldıklarında alternatif aramaktan vazgeçtiklerini ortaya koymuştur. Tanınmayan bir gıdanın tadına baktıklarında alternatif değerlendirmesi yapmak isteyen tüketiciler, tanıdık bildik bir tat ile karşılaştıklarında yüksek oranda marka bilinirliği bilinci ile o ürüne yönelmektedirler (Hoyer ve Brown, 1990, s. 141).

\section{Marka Çăgrısımlatı Yaratmada Duyusal Uyarıcılanın Tutuma Olan Etkisi}

Marka bilinirliğinden sonra markaya ilişkin çağrışım elde etmek gerekmektedir. Çünkü bilinirlik sağlanmadan çağrışım elde etmek mümkün değildir. Marka hakkında bilgi sahibi olan ve rakiplerinden kolayca ayrışan markalar, tüketici zihinlerinde marka ile ilgili zihinler şemalar tasarlamaktadırlar. Zihinsel şemalar ile marka eşleşmesi sağlandığında da markaya ilişkin çağrışımların önü açılmaktadır. Söz konusu bu zihinsel şemalar ise duyusal uyarıcılar sayesinde elde edilmektedir. Örneğin, Windows'a aşina olan tüketiciler gözlerini kapattığında bazılarının aklına Windows'un açılış sesi gelirken, bazılarınsa dört renkli logosu gelmektedir. İşte bu durum markanın duyusal imzasını hangi duyusal uyarıcıya yönelik oluşturduğuna bağlı olarak değişmektedir (Romaniuk, Wight ve Faulkner, 2017, s. 470; Krishna, 2016, s. 16).

Çağrışımlar kurulurken markanın hitap ettiği hedef kitlenin doğru saptanması çok önemlidir. Örneğin görsel uyarıcıların kullanılması planlandığında eğer üst sınıfa özgü yüksek fiyatlı bir ürün hedefleniyorsa çağrışım kurarken ambalaj tercihinde soğuk ve karanlık renkler ile kalın ve büyük yazılar tercih edilmektedir. Orta sınıf hedefleniyorsa ambalaj tasarımında düz, yatay çizgiler ve daireler tercih edilmektedir. Yine markanın sunduğu ürünlerin hangi cinsiyet grubunu hedeflediği, tüketicilerde hangi cinsiyete özgü çağrışımlarda bulunduğu önemli bir ayrıntıdır (Ampuero ve Vila, 2006, s. 105; Bruwer, Saliba ve Miller, 2011, s. 6). Markalar, pek çok görsel uyarıcı ile çağrışım elde edebilmektedir. Örneğin renkler, tüketici tutumlarını etkilemede daha çok sakinlik veya heyecan gibi duygusal dışa vurumları ortaya çıkarmaktadır. Ancak bunun haricinde bilişsel yönden de tüketicileri etkileyerek davranışa yönelmelerini sağlayabilmektedir.

Marka isimleri, sloganları, jenerik müziklerinin ritimleri de dilsel özellikler taşıdığından yüksek ses içermesi, sürekli tekrar edilmesi ile zihinsel şema oluşturmanın önü açılmaktadır. Bu anlamda çalan müziğin veya söylenen sloganın hangi markayı çağrıştırdığı bilişsel değerlendirmeler ile elde edilmektedir (Argo, Popa ve Smith, 2010, s. 97).

Koku içeren uyarıcılar da markalar tarafından tüketici çağrışımlarının elde edilmesi için oldukça sık kullanılan bir taktiktir. Kokunun özellikleri duyguları etkilemesi ve geçmiş deneyimlerle otobiyografik hafızayı etkin kılması duyuların aktive edilmesini sağlamaktadır. Örneğin büyükannesinin evi lavanta kokan bir çocuk, herhangi bir zaman diliminde lavanta kokusu duyduğunda aklına büyükannesinin gelmesi çağrışımların gücünü göstermektedir. Bu anlamda koku uyarıcıları olumlu veya olumsuz pek çok deneyimin açığa çıkmasını ve hatıllanmasını sağlaması açısından özellikle duygusal olmak üzere bilişsel ve davranışsal değerlendirmeleri de ortaya çıkarmaktadır (Augustin, Frankel ve Coleman, 2009, s. 55).

Dokunsal bir deneyim ile de çağrışımlar elde etmek mümkündür. Özellikle psikolojik sahiplik hissini yaşamak isteyen tüketiciler, ürünü kullanmayı tercih etmese bile ürüne dokunarak elde ettiği deneyim hoșuna gittiği için dokunma ihtiyacı duyabilir. Bu dokunuşun zihninde yarattığı çağrışımlardan hedonik fayda elde edilmesi, dokunsal özelliklerin bireylerde yarattı̆̆ duygusal değerlendirmelerin bir sonucudur (Peck, Barger ve Luangrath, 2013, s. 189-199). Diğer yandan ürün özellikleriyle ilgili bilgi edinmek gibi bilişsel değerlendirmeler de davranısssal değerlendirmelere dönüşebilir.

Tat duyusu da diğer tüm duyular gibi çağrışım elde etmede oldukça sık kullanılmaktadır. Fakat tat duyusunun genellikle diğer duyularla birlikte işlediği de bir gerçektir. Örneğin, salçalı ekmeği çocukluk dönemlerinde fazlaca tüketen bir birey, yetişkinlik dönemlerinden salçalı ekmeğin tadından çocukluk dönemlerine dönebilir ve o dönemlere ilisskin çağrışımlar elde edebilir. Ancak bu durumda salçalı ekmeğin kokusu, görüntüsü gibi diğer duyular da birlikte kullanılabilmektedir. Bu açıdan tat duyusunun tüketicilerde daha çok duygusal ancak bunun yanında bilişsel ve davranışsal değerlendirmeler sağladığı görülmektedir.

\section{Algılanan Kalite Oluşumunda Duyusal Uyarıcılann Tutuma Olan Etkisi}

Tüketicilerin herhangi bir markaya veya ürüne ilişkin algıladıkları değer, algılanan kalite yoluyla elde edilen faydalar, beklenti karşlıkları gibi unsurlar ile elde edilmektedir. Markaların kalite odaklı tüketiciye sundukları çağrışımlar, niteliksel faydalar, (Yan, 2019, s. 611) performans, işlevsellik, dayanıklılık, görsel 
çekicilik ve imaj gibi unsurlarla sağlanmaktadır. Olumlu imaj algısı doğrudan kalite algısını desteklemektedir. Bu nedenle olumlu kalite alg1sı sürekli tüketici memnuniyeti ve tüketici sadakati oluşumunun önünü açmaktadır (Pappu vd., 2005, s. 145). Olumlu kalite algısı yaratmada markalar, diğer tüm marka algısı boyutlarında olduğu gibi görme, işitme, koklama, dokunma ve tatma duyularının tamamın kullanabilir.

Görsel uyarıcılar, herhangi bir ürün hakkında bilgi sağlayan önemli bir değişkendir. Özellikle bilişsel değerlendirmeler ile ürünü kullanma noktasında bir karar mekanizması görevi görmektedir. Örneğin, manavda sebze meyve seçen bir tüketici, ürünlerin dış görünüşlerinden renklerinin tonundan tazelik ile ilgili sonuca varabilmekte ve bunun sonucunda bilişsel değerlendirmelerini davranışsal eylemlere dönüştürebilmektedirler.

Müzik ve tüketim ilişkisi bağlamında gerçekleştirilen tüketici araştırmalarında müzik ve tüketim arasında tüketicilerde zevk ve uyarılmayı aktifleştirdiği gerekçesiyle pozitif yönlü olumlu ilişkiler olduğu ortaya konulmuştur. Çoğunlukla bireysel değerlendirmeler tüketici tepkilerini etkilemektedir. Müziğin türü, tonu, ritmi ve hoşa gitme durumu tüketici tepkilerini önemli ölçüde etkilemektedir (Sweeney ve Wyber, 2002, s. 51). Bu tür işitsel uyarıcılar da markalar tarafindan ürün değerlendirmelerini olumlu şekilde etkilemek amacıyla tüketicilerin bilişsel, duygusal ve davranışsal tepkilerini yönlendirmek için bilinçli şekilde kullanılmaktadır.

Koku uyarıcılarına yönelik gerçekleștirilen bir araştırmada tüketicilerin hoș kokuya maruz kaldıklarında markaları daha olumlu değerlendikleri belirlenmiştir. Araştırma sonuçlarına göre hoş kokulu ortamlarda verilen kokular eğer tüketici kokuya aşina ise markayı daha olumlu değerlendirdikleri ve daha iyi bir duyusal bellek sergiledikleri saptanmıştır. Yine kokuların cinsiyetler bağlamında değerlendirilmesi tüketici tepkilerini belirleyebilmektedir. Buradaki olumlu değerlendirmenin kaynağı ise ortamda yayılmış olan hoş kokunun niteliğidir. Hoş kokulu ortamların daha kaliteli algılanması ise tüketici tercihlerinde yönlendirici olduğu ifade edilmiştir (Morrin ve Ratneshwar, 2000, s. 157; Stephens, 2017, s. 86). Bu nedenle koku uyarıcıların tüketicilerin duygusal ve bilişsel tepkilerini etkisi altına alarak davranışsal niyete dönüşmesini sağlamaktadır.

Nesnelerin fiziki özellikleri ürün kalitesinin belirlenmesinde önemli bir unsurdur. Çünkü tüketiciler herhangi bir ürün tercihinde, ürüne dokunarak onunla ilgili bilgi edinmek ve kalitesini anlayabilmeyi amaçlamaktadır (Vietoris, 2017, s. 19). Genellikle kozmetik, tekstil veya gıda gibi ürün kategorilerinde dokunma eylemi, kalite algısının oluşması ve bilişsel olarak ürünlerin satın alınıp alınmamasında belirleyici olabilmektedir.

Tat duyusu ile elde edilen lezzet algısı doğrudan kalite algısına referans olmaktadır. Özellikle gida sektöründe gerçekleştirilen kör testler, gerçek kalite ve gerçek lezzet algısının açığa çıkmasını sağlamaktadır. Örneğin Coca Cola ve Pepsi markaları, gazlı içecek kategorisinde tadım testleri ile tüketicilerin lezzet algılarının ortaya konulmasını amaçlamaktadır. Bu açıdan tat duyusunun kalite algısına olan katkısı daha çok bilişsel ve davranışsal eylem boyutlarında gerçekleşmektedir.

\section{Marka Sadakati Yaratmada Duyusal Uyarıcıların Tutuma Olan Etkisi}

Tüketiciler ve marka arasında süreklilik ve tutarlılık arz eden güçlü bağlar, zamanla tekrar eden satın alımlar ile sadakate dönüşmektedir (Suhonen ve Tengvall, 2009, s. 53; Oliver, 1999, s. 34-35). Söz konusu sadakatin temel nedeni ise tüketicilerin bireysel değerlendirmeler ile markaya yönelik ortaya çıkan olumlu tutumlarıdır. Tutumların, dışa vurumu ise bilişsel, duygusal ve davranışsal eylem şeklinde gerçekleşmektedir (Dick, 1994, s. 99). Olumlu tüketici tutumlarını elinde bulundurmak isteyen markalar ise çoğunlukla bunu duyusal uyarıcılar aracılığıyla gerçekleştirmektedirler.

Görsel girdilerin tüketicilerde herhangi bir marka ile ilgili aşinalığı, çağrışımları ve kaliteyi elde ederek sürekli satın almayı teşvik etmesi oldukça sık kullanılan bir taktiktir. Ürünlerin ambalajları, renkleri, şekilleri veya diğer birçok değişken yeniden tercih edilme noktasında markalar için bir çıkış noktası olabilmektedir. Örneğin sırf ambalajı veya şişe çekiciliği nedeniyle belli bir parfüm markasını satın almak buna örnek olarak verilebilir. Bu nedenle genellikle duygusal şemalar olmak üzere bilişsel ve davranışsal tepkiler sürekli tercihleri teşvik edebilir.

Sonik (sonic) markalama, markalar tarafindan oldukça sık kullanılan ve markaya yönelik olumlu değerlendirmelerin ana kaynağı olabilen önemli bir stratejidir. Sesiyle öne çıkmayı amaçlayan markalar genellikle duyguları hedeflemekte ve böylelikle markaya ilişkin düzenli, sürekli ve tutarlı satın alımların önünü açmaktadır. İşitsel unsurların duygusal deneyimler ile tüketicilere nostaljik deneyimler yaşatması 
geçmiş yaşantıların geri çağırılmasında ve markaya ilişkin olumlu bir tutum oluşmasına katkı sağlamaktadır (Gustafsson, 2015, s. 20-21). Bu yöntemle duygusal tepkiler ile tüketiciler ikna edilip uzun dönemli güçlü bağlar kurmak mümkündür.

Kokunun tüketicilerde yarattı̆̆ his ve izlenim, markalar için oldukça avantajlı bir durumdur. Havaya yayılan moleküllerin tüketiciler üzerindeki bu denli güçlü etkisi, dürtüsel satın almayı dahi teşvik eden muazzam bir stratejidir. Çünkü dürtüsel satın alma davranışı, duygulanım odaklı, kendiliğinden ve aniden ortaya çıkan genellikle de güçlü ve 1srarcı bir satın alma olarak kendini göstermektedir. Bu açıdan duyusal çekicilik elde etmek ve tüketicileri sadık birer müşteri haline getirmede önemli bir yoldur. Örneğin Febreze markası kötü kokuları yok edici güçlü bir bilişsel iddia ile tüketicilerin duygusal olarak tatmin olmalarının önünü açan Mutlu Nefes Al (Breathe Happy) kampanyası gerçekleştirmiştir. Kampanya sonucunda çok çeşitli ödüller almasının yanı sıra marka değerini \%19 artıran Febreze, bu sayede ürününü 250 milyon kişiye ulaştırmış ve sadık müşteriler elde etmenin yolunu açmıştır (Van Dyck, 2017, s. 102; Hubert, Florack, Linzmajer ve Kenning, 2013, s. 862).

Diğger bir uyarıcı türü dokunsal girdiler, ürünlerle ilgili bilgi edinme noktasında tüketicilere değerli bilgi sunduğu için sadık müşteri elde etmenin önemli bir yoludur. Dokunmaya elverişli olan ürünler için markaların tüketicileri dokunmaya teşvik etmesi, kalite ve güven duygusunun beraber işlemesine ve dolayısıyla ürün tercihlerinin bilişsel duygusal ve davranışsal niyete dönüşmesinin önünü açmaktadır. Dokunma deneyiminin bu denli önemli olmasının bir diğer nedeni de dokunmatik telefonlar ile dokunma eylemine olan yatkınlığın artmasıdır. Dokunsal yüzeylere temas ederek karar vermek ve kararın devamlılı̆̆1 bu anlamda geniş çevrelerce kabul edilen yaygın bir görüştür.

Lezzet algısının kaynağı olan tat girdileri, bireysel ve durumsal pek çok faktörden etkilenmektedir. Lezzet algısına yönelik gerçekleştirilen bir araştırmada tanıdık bir markanın içeriğinde gerçekleştirilen bilinçli bir değişiklik tüketiciler tarafından hemen fark edilmiş ve sadık müşterilerin tada ilişkin duyusal hafizalarının ne kadar güçlü olduğunu ortaya koymuştur. Dolayısıyla tadın bir markayı diğerlerinden ayırt edebilme noktasında bilişsel olduğu kadar duyguları da etkilediği ve davranışsal eyleme katkı sağladığı sonucuna varilabilir.

\section{Tartışma, Sonuç ve Öneriler}

Zorlu rekabet ortamında markalar farklılaşmak için çeşitli stratejiler kullanmaktadırlar. Bu farklılaştırma stratejileri maddi olduğu kadar maddi olmayan değerler üzerine kurulmaktadır. Bu kapsamda pek çok strateji bulunmaktadır. Bunlardan birisi de maddi olmayan değerler üzerine kurulmuş olan duyusal markalamadır. Duyusal markalama tüketicilerin beş duyu organlarına yönelik uyarıcıları hedefleyen, tutum ve alg1lar1 yönlendirmeyi amaçlayan bir markalama stratejisidir. Geleneksel yöntemlerin özellikle günümüz tüketicilerinin algıları ve tutumlarını etkilemedeki yetersizliği, markaları tüketicilerin duyularına yönelmeye sevk etmiştir.

Tüketiciler, ürün veya hizmet değerlendirmelerinde fonksiyonel faydanın yanında duygusal faydayı da gözetmektedir. Bunu gerçekleştirmenin ise en etkili yolu duyusal markalamadır. Beş duyu organından elde edilen duyusal girdiler, doğrudan bireylerin yaşam biçimleri ve bu doğrultuda tüketim tarzlarını şekillendirmektedir. Bu tüketim şeklinin açı̆̆a çıkarılması, markalara ilişkin alg1 ve tutumların yönlendirilmesi ile mümkündür.

Alg1 ve tutumların marka lehine çevrilmesinde marka algısı boyutları sahneye çıkmaktadır. Bu boyutlar; marka bilinirliği, marka çağrışımları, algılanan kalite ve marka sadakatidir. Duyusal girdilerin algılanması ve anlamlandırılması bireysel faktörlere göre farklılık göstermektedir. Bu faktörler her duyu özelinde her bireyi farklı tutum sergilemeye itmektedir. Örneğin, marka bilinirliği boyutunda bir markaya ilişkin inanç ve fikir bütünleşmesi bilişsel yönden oluşan şemalara bağlıdır. Öte yandan marka çağrışımları bilişsel olduğu kadar genellikle tüketicileri duygusal yönlerden etkisi altına almaktadır. Çünkü çağrışımlar zihinsel aktivitelerin uzun süreli ve tutarlı şekilde bellekte işlenmesini zorunlu kılmaktadır. Bellekte işlenen duyusal girdiler, marka ile eşleştiği ölçüde başarılı olmaktadır. Bu girdilerin rasyonel dünya ile eşleşmesi ve beklentilerin karşılanması ise alg1lanan kalite boyutu ile ilgilidir. Tüketicilerde kalite algısı, işlevsel veya hedonik faydanın karşılığını gördükleri oranda ortaya çıkmaktadır. Son marka algısı boyutu olan marka sadakati, markalama çalışmalarının nihai amacıdır. Bu kapsamda markaya yönelik uzun dönemli, tutarlı, sürekli ve tekrarlanan alımlar, bireylerin sadık birer müşteri olduğunu ortaya koymaktadır. 
Her marka algisı boyutunda olduğu gibi her duyunun insanları etkileme dereceleri de birbirinden farklıdır. Örneğin, koku içeren uyarıcılara karşı hassas olan bir tüketiciyi etkilemenin en elverişli yolu, ortama veya ürüne verilen hoş kokulardır. Ya da renklerin psikoloji üzerindeki baskın etkisiyle tüketiciler renk algıları ile etkilenebilmektedirler. Bu nedenle söz konusu bireysel farklılıklar göz önüne alınarak hangi tüketicinin hangi motivasyonel güç ile harekete geçirileceğinin belirlenmesi gerekmektedir.

Öznel değerlendirmelerin, marka algısı boyutları, tutumun bileşenleri ve beş duyu özelinde incelenebilir olması, duyusal markalama stratejisini benimseyen markalar için analiz edilmesi gereken öncelikli alanlardır. Çünkü mağaza ortamındaki ş̧ı̆̆ı parlaklı̆̆1 veya görünüşün cazibesi, çalan müziğin tonu, dokunulan kumaşın yumuşaklığı veya çevreye yayılan cezbedici koku, tüketicilerin duygu ve davranışlarını doğrudan etkisi altına almaktadır. Bu nedenle tüketiciler ürün hakkında satın alma kararı vermeden önce ürünü görmek, sesini duymak, koklamak, dokunmak veya tatmak istemektedirler. Dolayısıyla tüm bu uyarıcıların, markanın sunduğu ürün ve hizmete uygun şekilde kullanılması, tüketicilerin markaya yönelik algılarını etkilemektedir. Çünkü tüketici ile marka ilişkilerini yönetmek tüketicileri tatmin eden değişimlerin ve girişimlerin uygulanması ile mümkün olmaktadır.

Sonuç olarak bu çalışma, tüketicilerin bir markaya yönelik tutum geliştirmelerinde marka algisı boyutları olan bilinirlik, çağrışım, algılanan kalite ve sadakat ile sınırlandırılmıştır. Alan yazın taramasında duyusal markalama uyaranları ve tüketici tutumlarına yönelik olarak gerçekleştirilmiş nitel ve nicel araştırmalar bulunmaktadır. Ancak duyusal marka algısı boyutları ile tutum ilişkisine yönelik nitel ve nicel araştırmaların yapılması, duyusal markalama algısı literatürüne güncel ve etkin veriler sunulması açısından önemlidir.

\section{Etik Beyan}

"Duyum, Algi ve Marka: Tüketici Tutumlarna Yönelike Ü̧̧ Boyutlu Bir Değerlendirme” başlıklı çalışmanın yazım sürecinde bilimsel kurallara, etik ve alıntı kurallarına uyulmuş; toplanan veriler üzerinde herhangi bir tahrifat yapılmamış ve bu çalışma herhangi başka bir akademik yayın ortamına değerlendirme için gönderilmemiştir. $\mathrm{Bu}$ araştırma doküman incelemesine dayalı olarak yapıldığından etik kurul kararı zorunluluğu bulunmamaktadır.

\section{Kaynakça}

Aaker, D. (1991). Managing Brand Equity, John Wiley \& Sons.

Aaker, D.(1995). Building Strong Brands, The Free Press.

Alba, J. W. ve Hutchinson, J. W. (1987). Dimensions of consumer expertise. Journal of Consumer Research, 13(4), 411454.

Alpert, M. I., Alpert, J. I. ve Maltz, E. N.(2005). Purchase occasion influence on the role of music in advertising. Journal of Business Research, 58(3), 369-376.

Ampuero, O. ve Vila, N. (2006). Consumer perceptions of product packaging. Journal of Consumer Marketing, 23, 100112.

Amsteus, M. (2015). The scent of a successful venue (in) congruent scent and consumer attitude towards a cafe. International Journal of Business and Social Science, 6(5), 232-243.

Argo, J. J., Popa, M. ve Smith, M. C.(2010). The sound of brands. Journal of Marketing, 74(4), 97-109.

Augustin, S., Coleman, C. ve Frankel, N. (2009). Place advantage applied psychology for interior architecture. Wiley.

Axel, R. (1995). The molecular logic of smell. Scientific American, 16(3), 68-75.

Barat, A. H. (2007). Human perception and knowledge organization: visual imagery. Library Hi Tech, 25(3), 338- 351.

Beidler, L, M. (1988). Taste, (Ed.) J. M. Wolfe, Sensory Systems II: Senses Other than Vision. Boston: Birkhauser.

Berman, B. R., Evans, J. R. ve Chatterjee, P. M. (2013). Retail management: A strategic approach. United Kingdom: Pearson.

Büdün, E. ve Ertürk Y. D. (2020). Beş duyu kullanımı ile duyusal markalama: tüketici tutumlarını belirleme üzerine bir odak grup çalışması. Etkileşim, 5, 52-71.

Büdün, E. (2020). Markaya yönelik, tutum olusturmada duyusal markalama uyaranlarmmn rolï: Ev tekstili sektörü üzerine bir araştrma (Doktora Tezi). İstanbul Üniversitesi Sosyal Bilimler Enstitüsü, İstanbul.

Boone, L. E. ve Kurtz, D. L. (2011). Contemporary marketing. Cengage Learning.

Bosmans, A. (2006). Scents and sensibility: When do (in)congruent ambient scents influence product evaluations. Journal of Marketing, 70(3), 32-43.

Bradford, K. D. ve Desrochers, D. M. (2009). The use of scents to influence consumers- the sense of using scents to make cents. Journal of Business Etbics, 90(S2), 141-153.

Brugge, J. F. (1988). Auditory System, (Ed.) J. M. Wolfe, Sensory Systems II: Senses Other than Vision, Boston: Birkhauser.

Bruwer, J., Saliba, A. ve Miller, B. (2011). Consumer behaviour and sensory preference differences, implications for wine product marketing. Journal of Consumer Marketing, 28(1), 5-18. 
Buck, L. B. (2004). The search for odorant receptors. Cell, 116, 117-120.

Chang, H. H. ve Liu, Y. M. (2009). The impact of brand equity on brand preference and purchase intentions in the service industries. The Service Industries Journal, 29 (12), 1687-1706.

Crowley, A. E. (1993). The two-dimensional impact of color on shopping. Marketing Letters, 4(1), 59-69.

Cüceloğlu, D. (2006). Insan ve davranısı. İstanbul: Remzi Kitapevi.

Decre, G. B. ve Cloonan, C. (2019). A touch of gloss- haptic perception of packaging and consumers' reactions. Journal of Product \& Brand Management, 28(1), 117-132.

Dematte, M. L., Pojer, N., Endrizzi, I., Corollaro, M. L., Betta, E., Aprea, E., Charles, M., Biasioli, F., Zampini, M. ve Gasperi, F. (2014). Effects of the sound of the bite on apple perceived crispness and hardness. Food. Quality and Preference, 38, 58-64.

Dick, A. S. (1994). Customer loyalty: Toward an integrated conceptual framework. Journal of the Academy of Marketing Science, 2(2), 99-113.

Douglas, S. P., Craig, C. S. ve Nijssen, E. J. (2001). Integrating branding strategy across markets, building international brand architecture. Journal of International Marketing, 9(2), 97-114

Duizer, L. (2001). A review of acoustic research for studying the sensory perception of crisp, crunchy and crackly textures. Trends in Food Science \& Technology, 12(1), 17-24.

Elder, R. ve Krishna, A. (2010). The effect of advertising copy on sensory thoughts and perceived taste. The Journal of Consumer Research, 36(5), 748-756.

Ertürk, Y. D. (2017). Davranıslarmız ve biæ. İstanbul: Pozitif Yayınları.

Faircloth, J. B., Capella, L. M. ve Alford, B. L. (2001). The effect of brand attitude and brand image on brand equity. Journal of Marketing Theory and Practice, 9(3), 61-75.

Fitzgibbon, C. ve White, L. (2004). The role of attitudinal loyalty in the development of customer relationship management strategy within service firms. Journal of Financial Services Marketing, 9(3), 214-230.

Frank, M. E., Hettinger, T. P. ve Mott, A. E. (1992). The sense of taste: neurobiology, aging, and medication effects. Critical Reviews in Oral Biology \& Medicine, 3(4), 371-393.

Gallace, A. ve Spence, C.(2010). The science of interpersonal touch: An overview. Neuroscience \& Biobehavioral Reviens, 34(2), 246-259.

Grohmann, B., Spangenberg, E. R. ve Sprott, D. E. (2007). The influence of tactile input on the evaluation of retail product offerings. Journal of Retailing, 83(2), 237-245.

Gordon, W. (2006). What do consumers do emotionally with advertising? Journal of Advertising Research, 46(1), 2-10.

Gustafsson, C. (2015). Sonic branding: A consumer oriented literature review. Journal of Brand Management, 22(1), $20-$ 37.

Haase, J., Wiedmann, K. P. ve Labenz, F. (2018). Effects of consumer sensory perception on brand performance. Journal of Consumer Marketing, 35(6), 565-576.

Hakala, U., Svensson, J. ve Vincze, Z. (2012). Consumer-based brand equity and top-of-mind awareness: A crosscountry analysis. Journal of Product \& Brand Management, 21(6), 439-451.

Herrmann, A., Zidansek, M., Sprott, D. E. ve Spangenberg, E. R. (2013). The power of simplicity: processing fluency and the effects of olfactory cues on retail sales. Journal of Retailing, 89(1), 30-43.

Hoegg, J. ve Alba, J. W.(2007). Taste perception, more than meets the tongue. Journal of Consumer Research, 33(4) 490498.

Hoeksema, S. N., Fredrickson, B. L., Loftus, G. R. ve Wagenaar, W. A. (2009). Atkinson \& Hilgard's introduction to psychology. Wadsworth Pub Co.

Hornik, J. (1992). Tactile stimulation and consumer response. Journal of Consumer Research, 19(3), 449-459.

Hoyer, W. D., Brown, S. P.(1990). Effects of brand awareness on choice for a common, repeat-purchase product. Journal of Consumer Research, 17(2), 141-148.

Hubert, M., Florack, A., Linzmajer, M. ve Kenning, P. (2013). Neural correlates of impulsive buying tendencies during perception of product packaging. Psychology \& Marketing, 30(10), 861-873.

Hulten, B. (2011). Sensory marketing: The multi-sensory brand-experience concept. European Business Review, 23(3), 256-273.

Hussain, S. (2014). The impact of sensory branding (five senses) on consumer a case study on KFC (Kentucky Fried Chicken. International Journal of Research in Business Management, 2(5), 47-56.

Hsieh, M. H. (2004). Measuring global brand equity using cross-national survey data. Journal of International Marketing, $12(2), 28-57$.

Janiszewski, C. ve Meyvi, T. (2001). Effect of brand logo complexity, repetition, and spacing on processing fluency and judgment. Journal of Consumer Research, 28(1), 18-32.

Kardes, F., Cronley, M. ve Cline, T. (2010). Consumer Behavior. Cengage Learning.

Kellaris, J. J. ve Kent, R. J. (1993). An exploratory investigation of responses elicited by music varying in tempo. tonality, and texture. Journal of Consumer Psychology, 2(4), 381-401.

Keller, K. L. (2003). Brand synthesis: The multidimensionality of brand knowledge. Journal of Consumer Research, 29(4), 595-600.

Keller, K. L. (2013). Strategic brand management: Building, measuring, and managing brand equity. US: Prentice Hall. 
Keller, K. L. (2016). Reflections on customer-based brand equity: Perspectives, progress, and priorities. AMS Review, Academy of Marketing Science, 6(1-2), 1-16.

Klatzky, R. L. ve Peck, J. (2012). Please touch: Object properties that invite touch. IEEE Transactions on Haptics, 5(2), 139-147.

Krishna, A. ve Elder, R. (2009). The gist of gustation an exploration of taste, food, and consumption. In A. Krishna. (Edt.). Sensory marketing research on the sensuality of products. US: Routledge.

Krishna, A. (2016). Algz gerçektir, beş duyu satın alma davranıslarm nasıl etkiler? İstanbul: Ka Kitap.

Lancu I., Bara, M., Seserman, A. ve Bindea, A. (2009). Tune your brand In. The perfect jingle mix. Journal of Media Research, 5, 101-112.

Lazarus, R. S. (1991). Emotion and adaptation. USA: Oxford University Press.

Lindstrom, M. (2007). Duyular ve marka. İstanbul: Optimist Yayınları.

Lindstrom, M. (2017). Buy.ology. İstanbul: Optimist Yayınlar1.

Macinnis, D. J. ve Park, C. W. (1991). The differential role of characteristics of music on high- and low-involvement consumers' processing of ads. The Journal Of Consumer Research, 18, 161-173.

Mather, G. (2011). Essentials of sensation and perception. US: Routledge.

Mather, G. (2018). Duyu ve algımın temelleri (Çev: S. Canan ve R. Dokuyucu). Ankara: Nobel Akademi Yayıncıllk.

Meilgaard, B. ve Civille, C. T. (1999). Sensory Evaluation Techniques. CRC Press.

Medway, D. (2014). Rethinking Place Branding and the "Other" Senses, (Ed.) M. Kavaratzis, Warnaby, M., Ashworth, G., Rethinking Place Branding, Springer.

Montagu, A. (1971). Touching: The human significance of the skin. Columbia University Press.

Morgan, C. T. (2011). Psikolojiye Giriş, (Ed.) S. Karakaş, R. Eski. Eğitim Akademi Yayınları.

Morrin, M. ve Ratneshwar, S. (2000). The impact of ambient scent on evaluation, attention, and memory for familiar and unfamiliar brands. Journal of Business Research, 49(2), 157-165.

Morrin, M. (2009). Scent marketing an overview. In A. Krishna (Edt.). Sensory marketing research on the sensuality of products. US: Routledge.

Morschett, D., Swoboda, B. ve Foscht, T. (2005). Perception of store attributes and overall attitude towards grocery retailers: The role of shopping motives. The International Review of Retail, Distribution and Consumer Research, 15(4), 423-447.

Motameni, R. ve Shahrokhi, M.(1998). Brand equity valuation: A global perspective. Journal of Product \& Brand Management, 7(4), 275-290.

Moye, L. N. ve Kincade, D. H.(2003). Shopping orientation segments: exploring differences in store patronage and attitudes toward retail store environments among female apparel consumers. International Journal of Consumer Studies, 27(1), 58-71.

Mozell, M. M. (1988). Oflaction. In J. M. Wolfe (Edt.). Sensory Systems II: Senses Other than Vision. Boston: Birkhauser.

Mower, J. M., Kim, M. ve Childs, M. L. (2012). Exterior atmospherics and consumer behavior. Journal of Fashion Marketing and Management- An International Journal, 16(4), 442-453.

Noel, H. (2009). Basics marketing 01: Consumer behaviour. AVA Publishing.

Oliver, R. L. (1999). Whence consumer loyalty? Journal of Marketing, 63, 33-44.

Ozan, V. (2017). Kokular kitabı. İstanbul: Everest Yayınları.

Pappu, R., Quester, P. G. ve Cooksey, R. W. (2005). Consumer-based brand equity: Improving the measurement empirical evidence. Journal of Product \& Brand Management, 14(3), 143-154.

Peck, J. ve Childers, T. L. (2003a). Individual differences in haptic information processing: The 'Need for Touch' Scale. Journal of Consumer Research, 30(December), 430-42.

Peck, J. ve Childers, T. L. (2003b). To have and to hold, the influence of haptic information on product judgments. Journal of Marketing, 67(2), 35-48.

Peck, J. ve Childers, T. L. (2008). Effects of sensory factors on consumer behavior. In C. P. Haugtvedt, P. M. Herr, F. R. Kardes (Edt.). Handbook of Consumer Psychology. New York: Psychology Press.

Peck, J. (2009). Does touch matter? Insights from haptic research in marketing. In A. Krishna (Edt.). Sensory Marketing Research On The Sensuality of Products. US: Routledge.

Peck, J. ve Shu, S. B. (2009). The effect of mere touch on perceived ownership. Journal of Consumer Research, 36(3), 434-447.

Peck, J., Barger, V. A. ve Luangrath, A. W. (2013). In search of a surrogate for touch: The effect of haptic imagery on perceived ownership. Journal of Consumer Psychology, 23(2), 189-196.

Ries, A. ve Ries, L. (2019). Marka yaratmann 22 kural. İstanbul: MediaCat.

Rimkute, J., Moraes, C. ve Ferreira, C. (2015). The effects of scent on consumer behaviour. International Journal of Consumer Studies, 40(1), 24-34.

Robinson, E., Blissett, J. ve Higgs, S. (2013). The influence of recent tasting experience on expected liking for foods. Food Quality and Preference, 27(1), 101-106.

Romaniuk, J., Wight, S. ve Faulkner, M .(2017). Brand awareness: Revisiting an old metric for a new World. Journal of Product \& Brand Management, 26(5), 469-476.

Sayadi, M., Mobarakabadi, H. ve Hamidi, K. (2015). Sensory marketing and consumer buying behavior. Advanced Social Humanities and Management, 2(4), 100-104. 
Sharifi, S. (2014). Impacts of the trilogy of emotion on future purchase intentions in products of high involvement under the mediating role of brand awareness. European Business Review, 26(1), 43-63.

Schiffman, L. G. ve Wisenblit, J. (2015). Consumer behavior. Australia: Pearson.

Simss, C. D. ve Trott, P.(2006). The perceptions of the BMW Mini brand, the importance of historical associations and the development of a model. Journal of Product \& Brand Management, 15(4), 228-238.

Solomon, M. R., Bamossy, G., Askegaard, S. ve Hogg, M. K. (2006). Consumer behaviour: A European perspective. FT Press.

Solomon, M. R. (2017). Consumer behavior - Buying, having and being. Pearson.

Stephens, D. L. (2017). Essentials of consumer behavior. Routledge.

Stevenson, R. J. ve Boakes, R. A. (2004). Sweet and sour smells: learned synesthesia between the senses of taste and smell. In G. A. Calvert, C. Spence, B. E. Stein (Edt.). The Handbook Of Multisensory Processes. London: The Mit Press.

Suhonen, T. ve Tengvall, J. (2009). Branding in the air: A study about the impact of sensory marketing (Master's Thesis). Jönköping International Business School, Jönköping University, Sweden.

Sullivan, T., Hartley, J., Saunders, D., Montgomery, M. ve Fiske, J. (1994). Key concepts in communication amd cultural studies. London: Routledge.

Sweeney, J. C. ve Wyber, F. (2002). The role of cognitions and emotions in the music-approach-avoidance behavior relationship, Journal of Services Marketing, 16(1), 51-69.

Tom, G. (1990). Marketing with music. The Journal of Consumer Marketing, 7(2), 49-53.

Travis, D. (2000). Emotional branding: How successful brands gain the trrational edge. Crown Business.

Tuominen, P. (1999). Managing brand equity. The Finnish Journal of Business Economics, 1, 65-100.

Van Dyck, F. (2017). Yeni nesil reklamcilı.. İstanbul: The Kitap.

Vasudevan, S. ve Kumar, P. (2019). Changing realty: Altering paths of brand discovery for real estate websites in India. Property Management, 37(3), 346-366.

Vietoris, V. (2017). Introduction to sensory marketing. In E. Sendra, A. A.Carbonell-Barrachina (Edt.). Sensory and Aroma Marketing, Wageningen. Academic Publishers.

Yan, B. (2019). Research on the influence of customer perceived value on brand equity. American Journal of Industrial and Business Management, 9, 609-626.

Yi, Y. ve Jeon, H. (2003). Effects of loyalty programs on value perception, program loyalty, and brand loyalty. Journal of the Academy of Marketing Science, 31(3), 229-240.

Yoo, B., Donthu, N. (2001). Developing and validating a multidimensional consumer-based brand equity scale. Journal of Business Research, 52(1), 1-14.

Wanke, M. (2008). Social psychology of consumer behavior. Psychology Press.

Wilson, R. ve Gilligan, C. (2005). Strategic marketing management. Butterworth-Heinemann.

\section{EXTENDED ABSTRACT}

There are many strategies that brands have developed to influence consumer attitudes. The purpose of developing these strategies is to make a difference in a competitive environment where products and brands are gradually becoming alike due to the inadequacy of traditional methods to reach consumers. For this reason, brands have turned to consumer senses. The necessity of making a mark through the senses is a result of the effort of completely differentiation. Trying to influence consumers with their five senses is a strategic advantage to improve brand perception and consequently to direct attitudes. As consumer profiles and consumption patterns change, brands include differences in their product and service offerings to keep up with this change. The main purpose is to influence consumer attitudes.

Therefore, brands have started to use color, sound, smell, tactile element or taste elements and the sensory properties of products as a branding strategy. Visual stimuli consist of elements that appeal to the sense of vision such as color, lighting, packaging, package design, architectural structure, logo, and emblem. The auditory stimuli consist of auditory elements such as the product's own sound, store music or the brand's slogan. Odor stimulants are also the scent of the product itself, as well as the ambient scents used in the store, where the brand offers its products to the consumer. Tactile stimuli are the totality of properties such as weight, temperature, hardness, which are mostly used to express the properties of the product. Finally, taste stimulants are the taste perceptions obtained from the product's own taste. In a store environment, the brightness of the light or the appeal of the appearance, the tone of the music playing, the softness of the fabric touched or the attractive smell emanating from the environment directly affect the emotions and behaviors of the consumers. Because consumers want to see, hear, smell, touch or taste the product before choosing the product. Therefore, the use of all these stimulants in accordance with the product and service offered by the brand affects the perceptions of the 
consumers towards the brand. Because managing consumer and brand relationships is possible with the implementation of changes that satisfy consumers.

The meaning of stimuli for sight, hearing, smell, touch and taste, which are obtained through the five senses, is realized through sensory perception. Although there are many factors that affect this perception process, the transformation of sensory perceptions into attitudes is possible with the conscious reactions of consumers. Although the subjective nature of perception makes it difficult to predict consumer behavior, handling the differences together can provide a generalized strategy. Not every sensory input can be expected to affect all consumers at the same rate. However, using one or more of the five sensory organs to create multiple contact points can be effective in turning consumer perceptions in favor of the brand. The perception and interpretation of sensory inputs differ according to individual factors. These factors push each individual to exhibit a different attitude in each sense. For example, in the brand awareness dimension, the integration of beliefs and ideas about a brand depends on cognitive schemas.

On the other hand, brand associations generally affect consumers emotionally as well as cognitively. Because associations necessitate mental activities to be processed in memory for a long time and consistently. Sensory inputs processed in memory are successful to the extent that they match the brand. Matching these inputs with the rational world and meeting the expectations are related to the perceived quality dimension. The perception of quality in consumers arises at the rate they see the return of functional or hedonic benefits. Brand loyalty, the last dimension of brand perception, is the ultimate goal of branding studies. In this context, long-term, consistent, continuous and repetitive purchases of the brand reveal that individuals are loyal customers to that brand and function in cognitive, emotional and behavioral action dimensions.

In this study an evaluation has been made on what kind of effect the inputs on vision, hearing, smell and touch have on consumers' attitudes towards the brand. This evaluation was carried out through three dimensions of attitude, cognitive, emotional and behavioral. According to the literature review, the mental knowledge, emotion and intention that consumers have about the product or brand affect their perceptions and attitudes towards the brand. Brand perception dimensions that affect attitude formation were also included in the study. These dimensions are brand awareness, brand associations, perceived quality and brand loyalty. It has been observed that brand perception is affected by all five senses separately, and this level of influence differs according to the quality of the brand or product. In summary, according to the sources of the literature, it motivates consumers through five senses, cognitive descriptions and emotional schemas and drives them to behavioral action. 